\title{
AGREEMENT BETWEEN ORTHODONTISTS IN THE DIAGNOSIS OF SAGITTAL FACIAL PATTERNS
}

\author{
CONCORDÂNCIA DE ORTODONTISTAS NO DIAGNÓSTICO DOS PADRÕES \\ SAGITAIS DA FACE
}

\author{
Talita Araújo VAZ ${ }^{1}$; Catielma Nascimento SANTOS ${ }^{2}$; Henrique Damian ROSÁRIO $^{3}$; \\ Graziela Oro CERICATO ${ }^{4}$; Gustavo Mussi Stefan OLIVEIRA ${ }^{5}$; Luiz Renato PARANHOS ${ }^{6}$ \\ 1. Private Practice, Brazil; 2. Department of Dentistry, Universidade Federal de Sergipe, Lagarto, SE, Brazil; 3. Department of \\ Orthodontics; Faculdades Integradas do Norte de Minas - FUNORTE, Florianópolis, SC, Brazil; 4. School of Dentistry, Faculdade \\ Meridional - IMED, Passo Fundo, RS, Brazil; 5. University of Louisville School of Dentistry, Louisville, Kentucky, USA; \\ 6. Universidade Federal de Sergipe, Lagarto, SE, Brazil. paranhos@ ortodontista.com.br
}

\begin{abstract}
The cephalometric analysis has assisted orthodontics in describing face features in terms of numbers/angles, but these results are not always consistent with ideal individual patterns. Some orthodontists have made use of subjective analysis as an auxiliary method in the diagnosis; however, the consistency of the reproducibility of these methods has been questioned. Hence, this study aimed to verify whether the diagnosis of sagittal facial patterns can be accomplished with a reliable reproduction. This is an analytical observational study including an initial sample of 120 teleradiographs and 120 photographs in lateral norm of patients from the Graduate Program in Dentistry, Faculty of Health of the Methodist University of São Paulo. First, a previously calibrated examiner separated the photographs into three Sagittal Facial Patterns (Pattern I, II and III). Thus, it was obtained three groups comprising 45 photographs for the Pattern I; 45 photographs for the Pattern II and 30 photographs for the Pattern III. After this initial selection, the cephalometric analysis of 120 teleradiographs was performed using measurements of ANB and SN-GoGn angles. From this second analysis, it was selected only the photographs in which the result of subjective analysis matched the cephalometric analysis, totalizing a final sample size of 52 photographs. These 52 photographs were separated and set on an album to be reassessed by 19 orthodontists, in order to observe or not an agreement between the facial patterns among professionals. The kappa test analyzed the level of agreement of 19 professionals in relation to the cephalometric reference. The degree of agreement between professional judgment and cephalometry was found to be $73.08 \%$, and the result of the kappa test was 0.59 (moderate agreement). Taken together, the accuracy in the diagnosis of facial pattern by means of subjective facial analysis demonstrates that the subjective method is reliable for clinical use.
\end{abstract}

KEYWORDS: Diagnosis. Orthodontics. Cephalometry. Face.

\section{INTRODUCTION}

In orthodontics, cephalometric analysis has gained prominence since the introduction of standardized teleradiography, given the possibility of translating the facial and teeth features into numbers (DIBBETS, 1996; GAZI-COKLICA et al., 1997). Nevertheless, despite being consecrated as a complementary examination of fundamental importance for the evaluation of dental and skeletal conditions, cephalometric analysis does not always provide data consistent with ideal individual patterns (RICKETTS et al., 1982; SILVA; TELLES, 1997; MARTINS; VIGORITO, 2012).

Accordingly, many orthodontists have currently taken into account subjective patterns during facial analysis, differing from the rigid patterns required by cephalometry (RICKETTS, et al., 1982). This subjective analysis has been proven to be effective in the evaluation of the facial features, but it has been criticized with regard to reliability as a means of diagnosis.
The facial pattern is established early in childhood and does not change with growth (BROADBENT; BROADBENT JR; GOLDEN, 1975; CHANG; KINOSHITA; KAWAMOTO, 1992; SILVA FILHO, MAGRO; OZAWA, 1992; CAPELOZZA FILHO, 2012). Given this, Capelozza Filho (2012) developed a diagnostic system based on a morphological analysis of the face using patients' front and profile photographs. The patterns were distinctly grouped into five categories, as follows: Pattern I, Pattern II, Pattern III, Long Face Pattern, and Short Face Pattern three sagittal and two vertical patterns, respectively. This subjective diagnostic method has been widely used in the literature (FERES; VASCONCELOS, 2009; MORIHISA; MALTAGLIATI, 2009; ZANGE et al., 2011; PARANHOS et al., 2014; CARDOSO et al., 2015). Thus, the objective of this study was to evaluate the agreement between orthodontists in determining the sagittal facial pattern by means of the morphological evaluation of the face. 


\section{MATERIAL AND METHODS}

This study was conducted after approval by the Research Ethics Committee of the Universidade Metodista de São Paulo (protocol \#376080-10), ensuring participants and researchers of any ethical and legal issues.

This was an analytical observational study including an initial sample of 120 teleradiographs and 120 photographs in lateral view, obtained from the medical records of the Post-graduate Program in Dentistry, Faculty of Health of Universidade Metodista de São Paulo. The records belonged to 120 Brazilian individuals aged over 11 years, with no history of orthodontic treatment and/or surgical absence of craniofacial malformations, major facial asymmetry, odontogenic abnormalities (clinically observed), and with the presence of all permanent teeth in occlusion - excluding third molars.

Initially, a single examiner previously trained made a selection using the photographs, in order to visually categorize the patients into one of the three groups - Facial Pattern I, II and III, (CAPEZOLLA FILHO, 2012). The photographs used were taken according to the method of photographic standardization described by Reis (REIS et al., 2006), using the following criteria: individuals in Natural Head Position (NHP); absence of interference in the face (earrings, piercings etc.); individuals should not be smiling.

Therefore, after subjective analysis of the face, subjects (individuals) were separated into three groups: 1. Facial Pattern I $(n=45) ; 2$. Pattern II $(n=$ 45); and 3. Pattern III $(n=30)$.

In order to confirm the diagnosis of the facial patterns, a single operator previously trained made manually the cephalometric tracings of the angles ANB and SN.GoGn on the teleradiographs in all groups. The identification of these anatomical marks was based on classical definitions available in the literature (MIYASHITA, 1996).

Teleradiographs that did not fit the established value for each pattern were excluded from the initial sample $(n=120)$ : Pattern I, ANB = $2.43^{\circ}$ (0.96 to 3.9) and SN.GoGn $=29.24^{\circ}(25.05$ to 33.43) (REIS et al., 2005); Pattern II, $\mathrm{ANB}=4.15^{\circ}$ (2.07 to 6.23) and SN.GoGn $=28.58^{\circ}$ (23.5 to 33.66) (SILVA FILHO et al., 2009); Pattern III, $\mathrm{ANB}=-4.07^{\circ}(-1.78$ to -6.36$)$ and SN.GoGn $=$ $30.95 \circ$ (26.52 to 35.38) (PEREIRA, 2013), resulting in a new sample size redistributed as follows: Facial Pattern I group - composed of 19 individuals of different ages (14 females and 5 males); Pattern II group - composed of 18 subjects (10 females and 8 males); and Pattern III group - composed of 15 subjects ( 3 females and 12 males), totalizing 52 subjects ( 27 female and 25 male).

Then the photographic images of the 52 individuals were printed on photo paper with 300 dpi resolution. The original color was changed to grayscale to allow observing a satisfactory contrast between the area corresponding to the median sagittal plane and the background of the photographic image, so that the facial features such as skin tone and hair color would not influence the examiners in the evaluation of the face.

The 52 photographs were randomly arranged to compose a photographic album so that each examiner would evaluate only one photo at a time.

This step included a group of 19 examiners, experts in orthodontics. Each examiner was previously instructed and given a maximum of 15 seconds to analyze each photographic image and then classify the face of individuals according to Facial Pattern I, II or III.

The analysis of the method error in relation to the subjective assessment (intra-examiner) was verified by the Kappa test (0.75), and rated as fair to good (LANDIS; KOCH, 1977). Still as part of the assessment of the error, after a period of 15 days, the examiner retraced $30 \%$ of the 120 teleradiographs (totalizing 36 teleradiographs). In order to check the systematic error, paired " $t$ " test was used with a significance level of $5 \%$. The random error was determined by using the error calculation proposed by Dahlberg (HOUSTON et al., 1983): Error $=\sqrt{ } \sum \mathrm{d}^{2} / 2 \mathrm{n}$, where $\mathrm{d}=$ difference between the $1^{\text {st }}$ and $2^{\text {nd }}$ measurements, and $\mathrm{n}=$ number of radiographs retraced.

For inter-examiner agreement concerning the cephalometric reference, it was used the kappa statistic recommended by Fleiss, 1973. For the interpretation of kappa values obtained, the analysis of Landis e Kooch (1977) was used, which classifies $<0$ as no agreement, $0-0.19$ as poor agreement, 0.200.39 as fair agreement, $0.40-0.59$ as moderate agreement, $0.60-0.79$ as substantial agreement e $0.80-1.00$ as almost perfect agreement. Tests of system and casual errors showed no statistically significant results, demonstrating a good reliability of the method $(\mathrm{P}<0.05)$ [Table 1]. The results of the Kappa test showed significant concordance $(\mathrm{k}=$ 0.59) $(\mathrm{P}<0.05)$. Thereby, the concordance value can be considered as "moderate". 


\section{RESULTS}

According to the cephalometric classification, of the 52 subjects evaluated a total of $36.54 \%$ were classified as Pattern I ( $n=19), 32.69 \%$ as Pattern II $(\mathrm{n}=17)$ and $30.77 \%(\mathrm{n}=16)$ as Pattern III.
The individual agreement of each examiner in relation to the cephalometric parameters is shown in Table I. The median of agreement between the 19 examiners in relation to the cephalometric reference was $73.08 \%$ (kappa $=0.59$ ), rated as moderate according to Landis and Kooch, 1977.

Table 1. Individual agreement of each examiner in relation to the cephalometric reference.

\begin{tabular}{ccc}
\hline Examiner & \% agreement & Kappa \\
\hline $\mathbf{1}$ & 73.08 & 0.60 \\
$\mathbf{2}$ & 73.08 & 0.60 \\
$\mathbf{3}$ & 65.38 & 0.48 \\
$\mathbf{4}$ & 65.38 & 0.48 \\
$\mathbf{5}$ & 69.23 & 0.54 \\
$\mathbf{6}$ & 76.92 & 0.65 \\
$\mathbf{7}$ & 76.92 & 0.65 \\
$\mathbf{8}$ & 76.92 & 0.65 \\
$\mathbf{9}$ & 73.08 & 0.59 \\
$\mathbf{1 0}$ & 67.31 & 0.51 \\
$\mathbf{1 1}$ & 65.38 & 0.48 \\
$\mathbf{1 2}$ & 76.92 & 0.65 \\
$\mathbf{1 3}$ & 69.23 & 0.54 \\
$\mathbf{1 4}$ & 71.15 & 0.56 \\
$\mathbf{1 5}$ & 71.15 & 0.56 \\
$\mathbf{1 6}$ & 75.00 & 0.62 \\
$\mathbf{1 7}$ & 76.92 & 0.65 \\
$\mathbf{1 8}$ & 75.00 & 0.62 \\
$\mathbf{1 9}$ & 67.31 & 0.51 \\
Median & 73.08 & 0.59 \\
\hline
\end{tabular}

\section{DISCUSSION}

Despite the fact that cephalometric measurements are routinely used, there is no consensus as to the best method to determine the relationship between the apical bases, since there is a weak agreement between the different analyses (ARAT et al., 2008; OLIVEIRA; CANDEMIL, 2013). Thereby, it is essential for one not to undertake the analyses alone, but associated with other methods (ARAT et al., 2008; SALMÓRIA et al., 2014).

Capelozza Filho (2012) defines facial pattern as the configuration of the face over time whose characteristics are established very early in childhood and do not change throughout the years (BROADBENT; BROADBENT JR; GOLDEN, 1975; CHANG; KINOSHITA; KAWAMOTO, 1992; SILVA FILHO; MAGRO; OZAWA, 1992). The classification of the patterns proposed by Capelozza Filho (2012) is the result of a set of clinical experiences; therefore, a morphological diagnosis of the face allows the professional to determine the treatment plan based on the patients' limitations, in order to fulfill their needs without the demand for measures based on population average or even dental changes that compromise facial esthetics.

Nevertheless, the reproducibility of this analysis, which has a subjective nature, may be questioned, especially when performed by orthodontists with little experience. Furthermore, slight discrepancies are more difficult to be detected when compared to the large ones. This issue becomes more relevant by the fact that different diagnoses lead to different treatments (ARAT et al., 2008).

In this study, it was aimed to evaluate the degree of agreement regarding the sagittal cephalometric diagnosis defined by subjective analysis (CAPEZOLLA FILHO, 2012) and confirmed by cephalometric measurements. Cephalometric analysis was selected to assist in the diagnosis of anteroposterior maxillary and mandibular position, because it is a valid method of diagnosis (simply implemented and performed), particularly for the angles ANB and SN.GoGn (DOWNS, 1948). The association of these two 
measures reduces the influence of vertical factors on the reliability of the cephalometric diagnosis.

The subjective assessment was performed using photographs, which are a fundamental resource for determining the facial pattern. Moreover, when properly taken, photographs can be used in the objective assessment, such as in the measurement of sagittal and vertical angles (GOMES et al., 2013).

Although the subjective classification has many advantages, the professional must possess theoretical knowledge and appropriate training to reliably classify the facial pattern (REIS et al., 2011). This reason justified the choice for 19 expert examiners in orthodontics. Given the knowledge received during years of study and clinical practice, the professionals could classify the faces with better consistency, as they were less susceptible to external influences (visual and printed media) (TREVISAN; GIL, 2006). The potential clinical use for such an analysis may aggregate value to orthodontic diagnosis and planning, given that the facial configuration of the patient is being considered and respected (FERES; VASCONCELOS, 2009; MARTINS; VIGORITO, 2012).

All examiners showed agreement ranging from fair to good, according to the Kappa test
(LANDIS; KOCH, 1977). This result demonstrates the feasibility and clinical applicability of the method proposed by Capelozza Filho (2012).

It is worth noting that due to the subjective nature of aesthetic perception, the level of facial attractiveness is a very unique aspect varying in each person (SILVA et al., 2011). However, in order to consider a smile as aesthetically pleasant, one should evaluate the harmony of teeth along with the positioning of gingival and soft tissues (MOKHTAR et al., 2015), in addition to the shape of teeth and arch, and teeth color (PITHON et al., 2013).

Given the shortcomings of this study, particularly the sample size, further research is suggested to investigate agreement in diagnosis in view of the search for excellence in orthodontic treatment planning.

\section{CONCLUSION}

Based on the results obtained and in accordance with the methodology used, it is possible to conclude that there was accuracy in the diagnosis of facial pattern by means of the subjective facial analysis being reliable for clinical use.

RESUMO: A análise cefalométrica auxiliou a ortodontia a descrever numericamente as características da face, mas nem sempre estes resultados condizem com os padrões individuais ideais. Alguns ortodontistas utilizam análises subjetivas como método auxiliar no diagnóstico, porém a reprodução do método é discutida. Sendo assim, o trabalho objetiva verificar se o diagnóstico do Padrão sagital da face é possível de ser realizado com reprodução confiável. Trata-se de um estudo observacional analítico com uma amostra inicial de 120 telerradiografias e 120 fotografias em norma lateral de pacientes pertencentes ao Programa de Pós-Graduação em Odontologia da Faculdade da Saúde da Universidade Metodista de São Paulo. Primeiramente, um avaliador, previamente treinado, separou as fotografias nos Três Padrões sagitais da face (Padrão I, II e III). Dessa forma obtiveram-se três grupos compostos por 45 fotografias no Padrão I; 45 fotografias no Padrão II e 30 fotografias no Padrão III. Após essa seleção inicial foi realizado a análise cefalométrica das 120 telerradiografias desses pacientes utilizando as medidas dos ângulos ANB e SN.GoGn. A partir dessa segunda análise foram selecionadas apenas as fotografias em que o resultado da análise subjetiva coincidiu com a análise cefalométrica resultando em um novo número amostral final de 52 fotografias. Estas 52 fotografias foram separadas e montadas em um álbum para serem reavaliadas por 19 ortodontistas com o intuito de observar ou não a concordância dos Padrões Faciais entre os profissionais. Para a análise de dados utilizou-se o Teste Kappa com o intuito de analisar o nível de concordância dos 19 profissionais com a referência cefalométrica. Dessa forma, o grau de concordância entre a avaliação profissional e a cefalometria encontrado foi de 73,08\% sendo o resultado do Teste Kappa de 0,59 - considerado moderado. Conclui-se que existe exatidão no diagnóstico do padrão facial por meio da analise subjetiva da face, o que demonstra que este método subjetivo é confiável para a utilização na prática clínica.

PALAVRAS - CHAVES: Diangóstico. Ortodontia. Cefalometria. Face.

\section{REFERENCES}

ARAT, Z. M.; AKCAM, M. O.; ESENLIK, E.; ARAT, F. E. Incosistencies in the differential diagnosis of open bite. The Angle Orthodontist, Aplleton, v. 78, n. 23, p. 415-420, 2008. http://dx.doi.org/10.2319/021907-80.1

BROADBENT, B. H.; BROADBENT JR, B. H.; GOLDEN, W. H. Bolton Standards of dentofacial developmental growth. St. Louis: C. V. Mosby, 1975, 166 p. 
CAPELOZZA FILHO, Leopoldino. Diagnosis in Orthodontics. Maringá: Dental Press, 2012, 544 p.

CARDOSO, M. A.; PARANHOS, L. R.; SIQUEIRA, D. F.; GUEDES, F. P.; RHODEN, F. K.; CAPELOZZA FILHO, L. Agenesis of maxillary second premolar - diagnosis and clinical management. International Journal of Orthodontics, Milwaukee, v. 26, n. 1, p. 53-58, 2015.

CHANG, H.; KINOSHITA, Z.; KAWAMOTO, T. Craniofacial pattern of class III deciduous dentition. The Angle Orthodontist, Aplleton, v. 62, n. 2, p. 139-144, 1992.

DIBBETS, J. M. Morphological associations between the angle classes. European Journal of Orthodontics. London, v. 18, n. 2, p. 111-118, 1996. ttp://dx.doi.org/10.1093/ejo/18.1.111

DOWNS, W. B. Variations in facial relationship: their significance in treatment and prognosis.

The Angle Orthodontist, Aplleton, v. 19, n. 34, p. 145-155, 1948.

FERES, R.; VASCONCELOS, M. H. F. Comparative study between the subjective facial analysis and the soft tissue cephalometric analysis on the orthodontic diagnosis. Revista Dental Press de Ortodontia e Ortopedia Facial, Maringá, v. 14, n. 2, p. 81-88, 2009. http://dx.doi.org/10.1590/S1415-54192009000200010

FLEISS, Joseph L. Statistical methods for rates and proportions. New York: John Wiley \& Sons, 1973, 321 p.

GAZI-COKLICA, V.; MURITIC, Z.; BRCIC, R.; KERN, J.; MILICIC, A. Craniofacial parameters during growth from the deciduous to permanent dentition: a longitudinal study. European Journal of Orthodontics, London, v. 19, n. 6, p. 681-689, 1997. http://dx.doi.org/10.1093/ejo/19.6.681

GOMES, L. C. R.; HORTA, K. O. C.; GANDINI JR, L. G.; GONÇALVES, M.; GONÇALVES, J. R. Photographic assessment of cephalometric measurements. The Angle Orthodontist, Aplleton, v. 83, n. 6, p. 1049-1058, 2013. http://dx.doi.org/10.2319/120712-925.1

HOUSTON, W. J. B. The analysis of errors in orthodontic measurements. American Journal of Orthodontics and Dentofacial Orthopedics, St Louis, v. 83, n. 5, p. 383-390, 1983. http://dx.doi.org/10.1016/00029416(83)90322-6

LANDIS, J. R.; KOCH, G. G. The measurement of observer agreement for categorical data. Biometrics, Amsterdam, v. 33, n. 1, p. 159-174, 1977. http://dx.doi.org/10.2307/2529310

MARTINS, L. F.; VIGORITO, J. W. Photometric analysis applied in determining facial type. Dental Press Journal of Orthodontics, Maringá, v. 17, n. 5, p. 71-75, 2012. http://dx.doi.org/10.1590/S217694512012000500010

MIYASHITA, Kunihiko. Contemporary cephalometric radiography. Chicago: Quintessence Publishing Co, 1996, $291 \mathrm{p}$.

MOKHTAR, H. A.; ABULJADAYEL, L. W.; AL-ALI, R. M.; YOUSEF, M. The perception of smile attractiveness among saudi population. Clinical, Cosmetic and Investigational Dentistry, Auckland, v. 7, p. 17-23, 2015. http://dx.doi.org/10.2147/CCIDE.S74764

MORIHISA, O.; MALTAGLIATI, L. A. Comparative evaluation among facial attractiveness and subjective analysis of Facial Pattern. Revista Dental Press de Ortodontia e Ortopedia Facial, Maringá, v. 14, n. 6, p. 46.e1-46.e9, 2009. http://dx.doi.org/10.1590/S1415-54192009000600006

OLIVEIRA, M. T.; CANDEMIL, A. Assessment of the correlation between cephalometric and facial analysis. Journal of Research in Dentistry, North America, v. 1, n. 1, p. 34-40, 2013. 
PARANHOS, L. R.; BRANDO, T. M.; KAIEDA, A. K.; RAMOS, A. L.; TORRES, F. C. The Inadequacy of the Y-axis of Growth (Sngn) for the Vertical Pattern Assessment in Patients with Sagittal Discrepancies. The Journal of Contemporary Dental Practice, New Delhi, v. 15; n. 2; p. 174-178, 2014. http://dx.doi.org/10.5005/jp-journals-10024-1509

PEREIRA, C. V. C. A. Candidate genes and phototypic characterization of skeletal Class III malocclusion (dissertation). Rio de Janeiro, Brazil: Federal University of Rio do Janeiro; 2013.

PITHON, M. M.; SANTOS, A. M.; VIANA DE ANDRADE, A. C.; SANTOS, E. M.; COUTO, F. S.; COQUEIRO, R. S. Perception of the esthetic impact of gingival smile on laypersons, dental professionals, and dental students. Oral Surgery, Oral Medicine, Oral Pathology and Oral Radiology, New York, v. 115, n. 4, p. 448-454, 2013. http://dx.doi.org/10.1016/j.oooo.2012.04.027

REIS, S. A. B.; ABRÃO, J.; CAPELOZZA FILHO, L.; CLARO, C. A. A. Numeric facial analysis of the profile in Pattern I Brazilians. Revista Dental Press de Ortodontia e Ortopedia Facial, Maringá, v.11, n. 6, p. 24-34, 2006. http://dx.doi.org/10.1590/S2176-94512011000400012

REIS, S. A. B; ABRÃO, J.; CLARO, C. A. A.; FORNAZARI, R. F.; CAPELOZZA FILHO, L. Agreement among orthodontists regarding facial pattern diagnosis. Dental Press Journal of Orthodontics, Maringá, v.16, n. 4, p. 60-72, 2011. http://dx.doi.org/10.1590/S2176-94512011000400012

REIS, S. A. B.; CAPELOZZA FILHO, L.; CARDOSO, M. A.; SCANAVINI, M. A. Cephalometric characteristics assessment of Pattern I. Revista Dental Press de Ortodontia e Ortopedia Facial, Maringá, v.10, n. 1, p. 67-78, 2005.

RICKETTS, M.; ROTH, R. H.; CHACONAS, S. J.; SCHULHOF, R. J.; ENGEL G. A. Orthodontic diagnosis and planning: their roles in preventive and rehabilitative dentistry. 1 st ed. Denver: Rocky Mountain Orthodontics, 1982, $472 \mathrm{p}$.

SALMÓRIA, I.; FURTADO, A.; ROSÁRIO, H. D.; FURTADO, G. C.; PARANHOS, L. R. Arnett and Bergman facial analysis compared with aesthetic perception by lay people and dentists (general practitioners and orthodontists). Bioscience Journal, Uberlândia, v.30, n. 1, p.297-303, 2014.

SILVA FILHO, O. G.; BERTOZ, F. A.; CAPELOZZA FILHO, L.; ALMADA, E. C. Spontaneous facial growth in Pattern II: a longitudinal cephalometric study. Revista Dental Press de Ortodontia e Ortopedia Facial, Maringá, v. 14, n.1, p. 40-60, 2009. http://dx.doi.org/10.1590/S1415-54192009000100005

SILVA FILHO, O. G.; MAGRO, A. C.; OZAWA, T. O. Morphological characterization of class III malocclusion in the deciduous and mixed dentation. Ortodontia, São Paulo, v. 30, n. 2, p. 7-20, 1997.

SILVA, N. C. F.; AQUINO, E. R. B.; MELLO, K. C. F. R.; MATTOS, J. N. R.; NORMANDO, D. Orthodontists' and laypersons' perception of mandibular asymmetries. Dental Press Journal of Orthodontics, Maringá, v.16, n.4, p.e1-8, 2011. http://dx.doi.org/10.1590/S2176-94512011000400007

SILVA, S. P.; TELLES, C. S. Evaluation of patients undergoing orthodontic treatment considered as having pleasant facial features. Part I. Revista da Sociedade Brasileira de Ortodontia, Rio de Janeiro, v. 3, n. 3, p. 86-90, 1997.

TREVISAN, F.; GIL, C. T. L. A. Photogrametric and subjective analysis of the facial profile in young subjects with normal occlusion. Revista Dental Press de Ortodontia e Ortopedia Facial, Maringá, v.11, n. 4, p. 2435, 2006. http://dx.doi.org/10.1590/S1415-54192006000400004

ZANGE, S. E.; RAMOS, A. L.; CUOGHI, O. A.; MENDONÇA, M. R.; SUGINO, R. Perceptions of laypersons and orthodontists regarding the buccal corridor in long- and short-face individuals.

The Angle Orthodontist, Aplleton, v. 81, n. 1, p. 86-90, 2011. http://dx.doi.org/10.2319/031210-145.1 